\title{
Multi-focal evaluation and establishment of primary care for recently incarcerated women
}

\author{
Diane S Morse ${ }^{1,2^{*}}$, John L Wilson ${ }^{1}$, Ann M Dozier ${ }^{3}$, Catherine Cerulli ${ }^{1,4}$ \\ From 2014 Addiction Health Services Research (AHSR) Conference \\ Boston, MA, USA. 15-17 October 2014
}

\begin{abstract}
Background
Individuals recently released from incarceration face challenges while accessing primary medical care, mental health care, addiction treatment, and medication [1]. Furthermore, women are the fastest growing incarcerated population and have additional health risks, such as histories of trauma, high-risk sexual behaviors, and increased risk of contracting HIV and hepatitis C [2]. Re-entering individuals often resort to emergency rooms, where they will not obtain adequate long-term strategies for treatment. Primary care clinics have been established for patients with substance abuse [3], with recent recommendations to add mental health care [2]. We examined effects of a transitions primary care clinic for recently released women housed in a department of psychiatry at an academic medical center.
\end{abstract}

\section{Materials and methods}

Formerly incarcerated community health workers (CHWs) recruited women $(\mathrm{N}=95)$ recently released and scheduled for release from jail, prison, probation, or transitional housing. Women who lacked an adequate primary care provider were recruited to attend the Women's Initiative Supporting Health (W.I.S.H.) Transitions Clinic between September 2012 and July 2014. W.I.S.H. is one of 11 culturally informed clinics within the Transitions Clinic Network consortium and employs trauma and culturally informed practices [4]. An internist (DSM) conducted comprehensive, multifocal evaluations on all clinic patients. The key aim of this project was to assess the extent to which screening and assessment resulted in patient follow-up recommendations for future testing. Of

\footnotetext{
* Correspondence: diane_morse@urmc.rochester.edu

'Department of Psychiatry, University of Rochester School of Medicine, Rochester, NY, 14642, USA

Full list of author information is available at the end of the article
}

primary interest were testing for HIV, hepatitis A, B, and $\mathrm{C}$, and sexually transmitted infections.

\section{Results}

Of the 95 women recruited (Table 1), 68 (72\%) attended the clinic at least once and completed the intake process. Women were recruited at the local jail $(n=26)$, transitional housing $(\mathrm{n}=21)$, community supervision programs $(n=12)$, shelters $(n=5)$, community agencies $(\mathrm{n}=2)$, and through self-referrals $(\mathrm{n}=2)$. The majority of patients who were referred to testing completed the testing (Table 2). Patients received mental health and addiction assessments (including nicotine) and were offered treatment.

\section{Conclusions}

Women recently released from incarceration to a clinic housed in psychiatry succeeded in linking patients to primary care and assessments. Formerly incarcerated CHWs

Table 1 Demographical information of individuals recruited from September 2012 to July 2014

\begin{tabular}{lllll}
\hline & \multicolumn{2}{c}{ Attended clinic } & \multicolumn{2}{l}{$\begin{array}{l}\text { Did not attend } \\
\text { clinic }\end{array}$} \\
\cline { 2 - 6 } & $\mathrm{N}$ & Percentage & $\mathrm{N}$ & Percentage \\
\hline Number of individuals recruited & 68 & - & 27 & - \\
Mean age & 37.3 & - & 34.4 & - \\
(SD) & $(11.1)$ & - & $(10.2)$ & - \\
Race: & & & & \\
African American & 26 & 38 & 14 & 52 \\
Caucasian & 36 & 53 & 13 & 48 \\
Asian & 1 & 2 & 0 & 0 \\
Other & 5 & 7 & 0 & 0 \\
Ethnicity: & & & & 81 \\
Hispanic & 6 & 9 & 22 & - \\
History of intimate partner & 42 & 62 & - & - \\
violence & & & & - \\
History of child abuse & 19 & 28 & - & \\
\hline
\end{tabular}


Table 2 Women's Initiative Supporting Health (W.I.S.H.) transitions clinic patient testing data from September 2012 to July 2014

\begin{tabular}{lll}
\hline & $\mathrm{N}$ & Percentage \\
Hepatitis A testing & & \\
Testing indicated/ordered & 62 & 91 \\
Completed testing & 39 & 72 \\
Hepatitis B testing & & \\
Testing indicated/ordered & 67 & 98 \\
Completed testing & 45 & 75 \\
Hepatitis C testing & & \\
Testing indicated/ordered & 63 & 92 \\
Completed testing & 42 & 71 \\
HIV testing & & \\
Testing indicated/ordered & 66 & 97 \\
Completed testing & 43 & 70 \\
Declined testing & 2 & 3 \\
Sexually transmitted infection testing & & \\
Testing indicated/ordered & 40 & 59 \\
Completed testing & 36 & 90 \\
\hline
\end{tabular}

recruited most women from incarceration and transitional housing. Clinics for justice-involved women using a trauma-informed approach may serve to improve these vulnerable patients' health, which in turn may improve the health of their families and communities. More study is needed to address potential policy changes required in hiring those with a felony history. Additionally, efforts to engage Hispanic women and those who declined testing are worthy of further explanation.

\section{Authors' details}

${ }^{1}$ Department of Psychiatry, University of Rochester School of Medicine, Rochester, NY, 14642, USA. '2Department of Medicine, University of Rochester School of Medicine, Rochester, NY, 14642, USA. ${ }^{3}$ Department of Public Health Sciences, University of Rochester School of Medicine, Rochester, NY, 14642, USA. ${ }^{4}$ Susan B. Anthony Center for Women's Leadership, University of Rochester, Rochester, NY, 14627, USA.

Published: 20 February 2015

\section{References}

1. Morse DS, Cerulli C, Bedell P, Wilson JL, Thomas K, Mittal M, Lamberti JS, Williams G, Silverstein J, Mukherjee A, Walck D, Chin N: Meeting health and psychological needs of women in drug treatment court. J Subst Abuse Treat 2014, 46:150-157.

2. Barnert ES, Perry R, Wells KB: Reforming healthcare for former prisoners. J Gen Intern Med 2014, 29:1093-1095.

3. Saitz R, Horton NJ, Larson MJ, Winter M, Samet JH: Primary medical care and reductions in addiction severity: A prospective cohort study. Addiction 2005, 100:70-78.

4. Wang EA, Hong CS, Samuels L, Shavit S, Sanders R, Kushel M: Transitions clinic: Creating a community-based model of health care for recently released California prisoners. Public Health Rep 2010, 125:171-177.

doi:10.1186/1940-0640-10-S1-A41

Cite this article as: Morse et al:: Multi-focal evaluation and establishment of primary care for recently incarcerated women. Addiction Science \& Clinical Practice 2015 10(Suppl 1):A41.

\section{Submit your next manuscript to BioMed Central} and take full advantage of:

- Convenient online submission

- Thorough peer review

- No space constraints or color figure charges

- Immediate publication on acceptance

- Inclusion in PubMed, CAS, Scopus and Google Scholar

- Research which is freely available for redistribution

Submit your manuscript at www.biomedcentral.com/submit 